MANAGING COST-BENEFIT ANALYSIS 
Other books by Grahame Walshe

International Monetary Reform

Mergers and Concentration in British Industry

(with P.E. Hart and M.A. Utton)

Planning Public Spending in the UK

Recent Trends in Monopoly in Great Britain 


\section{MANAGING \\ COST-BENEFIT \\ ANALYSIS}

GRAHAME WALSHE and

PETER DAFFERN

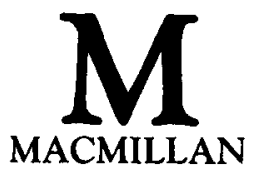


(C) Grahame Walshe and Peter Daffern 1990

All rights reserved. No reproduction, copy or transmission of this publication may be made without written permission.

No paragraph of this publication may be reproduced, copied or transmitted save with written permission or in accordance with the provisions of the Copyright, Designs and Patents Act 1988 , or under the terms of any licence permitting limited copying issued by the Copyright Licensing Agency, 33-4 Alfred Place, London WC1E 7DP.

Any person who does any unauthorised act in relation to this publication may be liable to criminal prosecution and civil claims for damages.

First published 1990

Published by

MACMILLAN EDUCATION LTD

Houndmills, Basingstoke, Hampshire RG21 2XS

and London

Companies and representatives

throughout the world

British Library Cataloguing in Publication Data

Walshe, Grahame

Managing cost-benefit analysis.

1. Cost-benefit analysis

I. Title II. Daffern, Peter

$339.4^{\prime} 1$

ISBN 978-0-333-48039-7

ISBN 978-1-349-20763-3 (eBook)

DOI 10.1007/978-1-349-20763-3 
To

Anthea

and

Helen 


\section{Contents}

List of Tables and Figures

Preface

xiii

1 Introducing the Case Studies 1

Constructing an analysis $\quad 3$

$\begin{array}{lr}\text { Concepts in benefit evaluation } & 9\end{array}$

$\begin{array}{ll}\text { Identifying costs } & 12\end{array}$

Discounting costs and benefits $\quad 17$

$\begin{array}{ll}\text { Discount rate alternatives } & 19\end{array}$

Does precision matter? $\quad 27$

Presenting the results $\quad 30$

Case study emphasis $\quad 35$

Notes $\quad 35$

Bibliography $\quad 37$

2 Health Care $\quad 39$

Introduction $\quad 39$

Cost-effectiveness and the provision of health care 41

Mudshire and Jollytown Health Authority 41

Health care outputs: beyond concern for costs 62

$\begin{array}{ll}\text { Conclusions } & 68\end{array}$

$\begin{array}{lr}\text { Notes } & 69\end{array}$

Bibliography $\quad 69$

Questions for discussion $\quad 71$

3 Privatising Public Sector Assets $\quad 72$

$\begin{array}{ll}\text { The Jaguar flotation } & 73\end{array}$

Outlining the public finance consequences $\quad 74$

$\begin{array}{ll}\text { Privatisation objectives } & 79\end{array}$

Efficiency improvement in Jaguar $\quad 81$

$\begin{array}{ll}\text { Conclusion } & 89\end{array}$

Annex Outline of typical steps to privatisation 90

Notes $\quad 94$ 
Bibliography $\quad 96$

Questions for discussion $\quad 96$

4 Assessing Transport Projects 98

Evaluation of some effects of transport projects $\quad 100$

Examples of the evaluation of transport projects 110

Conclusion $\quad 122$

Notes $\quad 122$

Bibliography 123

Questions for discussion $\quad 124$

5 Electricity Generation and the Case for Sizewell B 126

Introduction 126

Investment in electricity generation: the

Non-economic factors: broadening the analysis 136

Cost-benefit analysis of proposal to build a new power $\begin{array}{ll}\text { station - a framework } & 148\end{array}$

Notes $\quad 157$

Bibliography 157

Questions for discussion 158

6 The Trees in the Forest 159

Forestry in Great Britain 160

Costs and benefits in the 1972 Study 161

Changed assumptions 163

A commercial calculation $\quad 165$

Non-monetary costs and benefits $\quad 173$

Fiscal aids to forestry 181

Conclusion 184

Notes $\quad 185$

Bibliography 186

Questions for discussion $\quad 187$

7 Land Drainage and Irrigation $\quad 188$

$\begin{array}{ll}\text { Introduction } & 188\end{array}$

Elements of cost and benefit $\quad 189$

Objectives 191

Benefits and costs 192

Environmental effects $\quad 198$

Uncertainty $\quad 200$

The Yare barrier proposal $\quad 200$ 
A case study: dam or barrier proposal 204

Conclusion $\quad 210$

Notes $\quad 211$

Bibliography $\quad 211$

Questions for discussion $\quad 212$

8 'We Need a New Computer'

The submission 216

Observations on the submission $\quad 220$

Evaluating the benefits 226

Conclusion 238

$\begin{array}{ll}\text { Notes } & 238\end{array}$

Bibliography $\quad 238$

Questions for discussion $\quad 239$

9 The Appraisal of Private Financing 240

Public sector borrowing $\quad 241$

Public sector leasing $\quad 243$

Fiscal adjustments $\quad 246$

Real terms $\quad 247$

The method in outline: a telephone exchange 248

Rents 251

Tax incentives for capital equipment 255

A telephone exchange reconsidered 257

Corporation tax 261

Benefits of leasing 261

In conclusion: Is there a need for financing analyses? 263

Annex 1 The borrowing rate in the public sector 265

Annex 2 Paying rents in advance: adjustment $\begin{array}{ll}\text { factors } & 267\end{array}$

$\begin{array}{ll}\text { Notes } & 269\end{array}$

Bibliography 270

Questions for discussion $\quad 270$

10 Some Concluding Thoughts 271

Appendix Discounting Formulae and Tables 274

$\begin{array}{ll}\text { Index } & 280\end{array}$ 


\section{List of Tables and Figures}

\section{Tables}

1.1 Possible option time patterns of initial capital costs

1.2 Changes in road construction prices compared with the GDP deflator

1.3 Cost streams for a running track

1.4 Benefit cost ratios and net benefits: preventing flooding in a river basin

1.5 Form of appraisal submission 31

1.6 Stylised example of NPV decision matrix

2.1 Acute bed provision on current plans, 1988 and 2001, for Mudshire and Jollytown Health Authority

2.2 Estimated population of MJHA, 1988 and 2001

2.3 Summary of costs for five options

2.4 Acute beds provided under identified options in MJHA

3.1 Jaguar summary results, 1980-4

3.2 Illustrative scenarios for Jaguar 76

3.3 Discounted returns from selling/not selling Jaguar $\quad 78$

3.4 Jaguar shareholdings, 1985-9 82

3.5 Some financial and operating data for Jaguar, $1980-8$

4.1 Suburban rail services in Greater Manchester: benefits and costs of retention of 25 years of improved service

4.2 Suburban rail services in Greater Manchester: variants on the central case

4.3 SCOOT system costs, original system, Southampton

4.4 Benefitsinstudy area, Southampton SCOOT system 
4.5 Costs and benefits of SCOOT system, Southampton

5.1 Summary of net effective costs of Sizewell B, Scenario C

5.2 Cost of electricity from Sizewell B, medium nuclear background, Scenario $C$

5.3 Costs of power station: central case

5.4 Costs of power station - decommissioning postponed to year 50

5.5 Costs of power station - low coal price

5.6 Costs of power station: low coal price/decommissioning postponed

5.7 Present value of costs

5.8 Costs of power station: effects of increased disposal and decommissioning costs

6.1 Appraisal of costs and revenues, coniferous silviculture

6.2 Cumulative discounted and thinning revenues, Sitka spruce and Douglas fir

6.3 1985-6 new planting in South Scotland

6.4 A summary comparison of effects in four silvicultural systems

6.5 Two-option case, weighted utility aggregates

181

7.1 Yare Barrier flood protection, costs and benefits 201

7.2 Dam or barrier proposals, pattern of costs 205

7.3 Effects of changes in agriculture 205

8.1 Option 1: Susato 7/24 220

8.2 Option 2: Scheidt-Gabrieli 3/4.36 221

8.3 Option 3: Pezel $7000 \quad 222$

8.4 Option 4: Holborne 8/88 223

8.5 Option 5: Charpentier Flux 2000

8.6 Option 4 revised: Holborne 8/88 225

8.7 Examples of possible benefits arising from the use of new office technology 229

8.8 Computer acquisition: multi-attribute utility scoring 235

8.9 Cost-effectiveness and attribute analysis: Step One 236

8.10 Cost-effectiveness and attribute analysis: Step Two 237

8.11 Valued utility functions 237

9.1 Asset financing methods 245 
9.2 Discounting a stream of rentals

9.3 The present value of twenty quarterly payments of $£ 25,000$ in advance

9.4 Tax outflows on equipment leasing 256

9.5 The extra resource costs of leasing: exchange equipment

9.6 Present value of initial and residual capital values $\quad 259$

9.7 Telephone exchange leasing charges: short-cut method

9A.1 Adjustment factors

9A.2 Adjustment factors

A.1 Discount factors 277

A.2 Annuity factors 278

$\begin{array}{ll}\text { A.3 Equivalent annual value factors } & 279\end{array}$

\section{Figures}

1.1 Appraising a tunnel option 5

$\begin{array}{ll}1.2 & \text { Assessing a change in consumer's surplus } \\ 1.3\end{array}$

1.3 Production, national savings and capital accumulation

1.4 Optimal savings rate 25

3.1 Three operating ratios for Jaguar: $1980-8$ trends 88

3.2 Three operating ratios for Jaguar: 1980-4 trends 89

5.1 Factors at work in determining cost savings associated with the operation of a new power station

6.1 Illustrative utility functions

8.1 Typical procedural stages in information technology appraisal

8.2 Liberator payback chart 


\section{Preface}

Is there a need for another work on cost-benefit analysis? We are content to accept the market verdict on that question. Three features of the work, however, merit consideration by prospective readers.

First, the central aspect of each case study is the detailed setting out of the calculations. Our reading of the literature convinces us that this is an area which most precursor texts have regarded as far too mundane to treat seriously. However, students expecting to manage cost-benefit appraisals in their future careers will have to acquire skills in the construction and interpretation of cost and benefit data streams. We hope that these examples will provide an introduction to those skills.

Second, the emphasis here is on cost-benefit analysis as a management aid. Enough has been said in the literature for students to appreciate that it is often difficult to quantify and evaluate the impacts assessed in an appraisal. Accordingly practitioners rarely claim to produce a definitive cost-benefit statement. Rather, the analyst attempts to disclose the 'model' which confronts the decision-maker: benefit and cost outcomes may vary with different assumptions about the physical impacts; they may vary as the values placed upon key outputs are changed; and they may vary as the time profile of the benefits and costs is altered. All the potential sources of variation in model results should be disclosed. Each case study stresses the factors tending to increase managerial discretion, as opposed to those factors limiting the range of choice.

Third, in a number of cost-benefit appraisals there are residual categories of benefit and cost which prove impossible to evaluate. Nevertheless managers will normally wish to take such non-valued impacts into account in weighing up their decision. It is possible to suggest methods which systematically integrate non-valued 
impacts into the analysis. Where appropriate, we show how this can be done.

In compiling the text we received help and guidance from many kind people. In particular, we would like to thank Stephen Aldridge, Jean Entwistle, Pat Fordham, David Grundy, Edmund Hopkins, James Hunter, Bernard Meakins, Keith Povey and Anthea West. They cannot of course share the blame for any errors left undiscovered.

J.G.W. and P.A.D. 